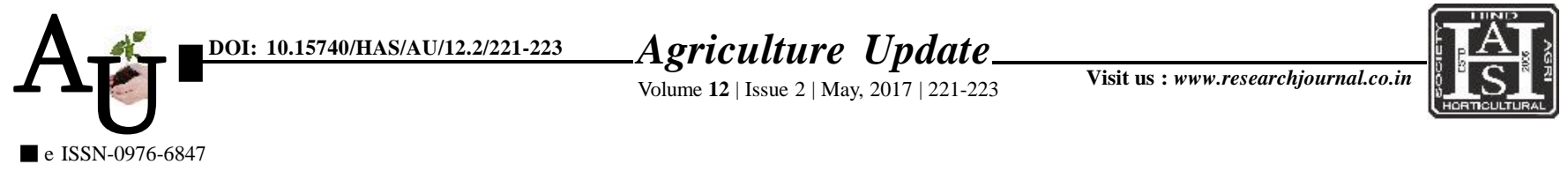

\title{
Research article: Constraints in adoption of recommended package of practices of greengram faced by the farmers in Nagaon district of Assam
}

\section{ARUP JYOTI GOSWAMI, CHANDAN KR. DEKA AND PABITRA KR. DAS}

Article Chronicle : Received : 30.01.2017;

Revised : 09.03.2017;

Accepted :

20.03.2017

Key Words:

Extent of adoption, Pulse crops, Package of practice

Author for correspondence :

\section{CHANDAN KR. DEKA}

Krishi Vigyan Kendra, DHUBRI (ASSAM) INDIA

Email:ckdeka@rediffmail.

com

See end of the article for authors' affiliations
SUMMARY : The study was carried out to see the extent of adoption of recommended package of practices of greengram and the problems faced by the farmers. The present study was conducted in Nagaon district of Assam. The survey was conducted in the month of February to March, 2016. The study revealed that the most important problems faced by majority of the pulse growers which ranked $1^{\text {st }}, 2^{\text {nd }}$ and $3^{\text {rd }}$ were non-availability of quality seeds, lack of irrigation facility and lack of knowledge on scientific cultivation of pulses. The other important problems which also need attention were high incidence of pest and diseases, post-harvest storage problem, price fluctuation in the market throughout the year, high cost of fertilizers and plant protection chemicals and flood damage the Kharif crops, lack of proper marketing facility, high rate of interest on loan charge by the professional money lender, high cost of certified seed/quality seeds, high incidence of intervention of middle men, complicated procedure for obtaining loan from the credit institution, heavy rainfall and lack of proper extension service.

How to cite this article : Goswami, Arup Jyoti, Deka, Chandan Kr. and Das, Pabitra Kr. (2017). Constraints in adoption of recommended package of practices of greengram faced by the farmers in Nagaon district of Assam. Agric. Update, 12(2): 221-223; DOI : 10.15740/HAS/AU/12.2/221-223. 